\title{
USGS Launches Online Database: Lichens in National Parks
}

Lichen lovers take note!

If you are interested in lichens and National Parks, now you can query a lichen database that combines these two elements. Using pull-down menus you can: search by park, specifying either species list or the references used for that area; search by species (a report will show the parks in which species are found); and search by reference codes, which are available from the first query. The reference code search allows you to obtain the complete citation for each lichen species listed in a National Park.

The result pages from these queries can be printed directly from the web browser, or can be copied and pasted into a word processor.

\begin{abstract}
What Are Lichens?
“Lichens are fungi that have formed symbiotic relationships with algal partners. The fungus provides a protective home, water supply and nutrient source for colonies of algae and/or cyanobacteria. In return for protection, the algal cells turn loose up to $70 \%$ of all the sugars harvested from their chlorophyll. The fungus uses these sugars as food. In turn, many animals use lichens as food."

http://www.nps.gov/olym/invlichen.htm
\end{abstract}

The database contains over 26,100 records of documented occurrences of lichens in U. S. National Parks. These records were obtained from the scientific literature, from National Park Service reports, and from the University of Minnesota Herbarium. Over 450 references that report lichens from 144 parks are included. A map shows which National Parks are included in this database (only parks with reported lichens are included). All lichen names were standardized to Esslinger's Checklist of North American Lichens.

\section{www.ies.wisc.edu/nplichen/}

This database was developed jointly by James P. Bennett, U. S. Geological Survey and

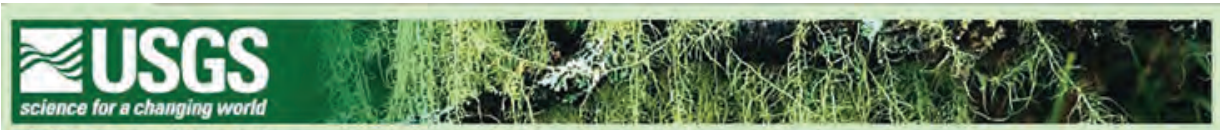

\section{NPLichen: A Database of Lichens in the U.S. National Parks \\ Please choose a national park below to obtain a list of lichen species that are \\ present in the park or to get a complete list of references for that park. Note: You \\ must specify either "Species List" or "References" in order for the query to work \\ Parks: \\ Acadia \\ Species List \\ References \\ Submit}

Please choose a lichen species below to see which parks each lichen species can be found in. If you cannot find the species you are looking for in this list, it may be species that we believe has been misidentified. Please check the complete list of Misidentified Lichen Species to find out.

Species: Abrothallus betianus $v \checkmark$ Submit

Please select a reference code below to obtain either the complete citation or a complete species list. Note: You must specify either "Full Reference" or "Species List" in order for the query to work

Reference Codes:

Ader \& Ahti1996

O Full Reference

Species List Submit
University of Wisconsin, Madison, WI and Clifford M. Wetmore, University of Minnesota, St. Paul, MN. Web site development was by Kara Jensen, with help from Paul Gunther, both at University of Wisconsin. The U. S. Geological Survey and the National Park Service provided funding for this database.

For technical questions about Web site content, please contact Jim Bennett at jpbennet@wisc.edu, (608) 262-5489, or Cliff Wetmore at wetmore@umn.edu, (612) 625-6292.

The NPLichen database can be queried by National Park, species, or reference code. 